\title{
KNOWLEDGE OF THE WEAPON IN PARTY LIABILITY CASES: AN ANALYSIS OF EDMONDS $V R$
}

\author{
Amy Hill*
}

This article explores the reasoning in Edmonds $\mathrm{v} \mathrm{R}$, the leading case in New Zealand on knowledge of the weapon in party liability cases. The Supreme Court concluded that there is no legal requirement to direct that a defendant must have known of a weapon to be guilty as a secondary party. There is a dichotomy between the approach in New Zealand and that adopted in the United Kingdom in similar situations. New Zealand has adopted an approach focused on harmful outcome whereas the United Kingdom decisions suggest a focus on the process involved in the crime. Because of these differing attitudes, it is undesirable for New Zealand to follow the United Kingdom in adopting a "knowledge of the weapon" direction as a matter of course in party liability trials. However, it appears that many lower court judges feel it is appropriately conservative to consider the defendant's foresight of a weapon for practical, evidential reasons. That approach has several merits but must remain confined to evidential aspects of the trial.

\section{INTRODUCTION}

The issue of whether knowledge of the weapon used in a group offence should be a requirement to convict a secondary party has been plaguing common law jurisdictions for years. This article examines the recent decision of Edmonds $v R(E d m o n d s)^{1}$ and goes on to discuss "knowledge of the weapon" requirements in joint enterprise party liability, governed by s 66(2) of the Crimes Act 1961. The chosen approach of the Supreme Court differs substantially from the development of this area in England and Wales (England). ${ }^{2}$ It reflects the codified nature of New Zealand's criminal provisions and a desire to keep the question of foresight of the ultimate harm at the centre of the analysis.

\footnotetext{
This article was submitted as part of the LLB(Hons) programme at Victoria University of Wellington. The author would like to thank Dr Yvette Tinsley for her support, advice and supervision.

1 Edmonds $v R$ [2011] NZSC 87, [2012] 2 NZLR 445.

2 For ease of use and conciseness "England" will be used to refer to the jurisdiction of England and Wales for
} the remainder of this article. 
Party liability under s 66(1) is outside the scope of this article and will not be discussed in any detail.

\section{A Purpose}

This article will explore the reasoning in Edmonds in more depth and in a thematic way. It is argued in Part III that the fundamental basis for the contrasting attitudes about how knowledge of the weapon fits into joint enterprise party liability comes down to a focus on combatting and punishing harm emanating from either the outcome or process of joint offending. New Zealand courts have focused on the harmful outcome. However in England more emphasis is given to the actions and processes causing that outcome. The "fundamentally different" rule adopted in England will be examined and the article will explore reasons why the rule is not considered appropriate in the New Zealand context. This issue is discussed in Part IV. In Part V of this article, the way that trial judges in New Zealand have commonly dealt with the complexities of s 66(2) will be analysed. Overall, it is submitted that the Supreme Court's approach to knowledge of the weapon directions under s 66(2) liability is legally correct and the most desirable approach for the New Zealand context.

\section{B Background - Section 66(2)}

Section 66(2) of the Crimes Act 1961 codified and modified the common law of joint enterprise party liability. It provides for secondary liability in situations involving group offending where the criminal actions of the principal offender are collateral to the common unlawful purpose.

Section 66(2) states:

Where 2 or more persons form a common intention to prosecute any unlawful purpose, and to assist each other therein, each of them is a party to every offence committed by any one of them in the prosecution of the common purpose if the commission of that offence was known to be a probable consequence of the prosecution of the common purpose.

Broken down, the requirements of s 66(2) are: ${ }^{3}$

(a) two or more people had an intention to commit a common unlawful purpose and aid each other in that;

(b) the principal offence was done in pursuit of the common unlawful purpose; and

(c) the principal offence was known to be a probable consequence of the common unlawful purpose. The meaning of "probable" is something that "could well happen".

The most significant issues to arise at trial relate to (a) and (c). These two aspects are also closely linked.

$3 \quad R v$ Gush [1980] 2 NZLR 92 (CA) most recently affirmed in $R v$ Vaihu [2009] NZCA 111 at [55]-[56]. 
Issues have arisen, especially in homicide cases, around the level of foresight or knowledge regarding the principal offence that is required of the defendant. ${ }^{4}$ Essentially opinions differ over the extent of detail of the crime the defendant must be aware of in order to be held responsible for the harm caused in the collateral offence. In s 167 homicide cases, a secondary party can be guilty of murder if they foresee a risk of killing or a risk that the principal may cause grievous bodily harm being reckless as to whether death ensues. In instances where the principal has committed s 168 murder a defendant can be guilty of murder as a party having foreseen only grievous bodily harm in the course of their common unlawful purpose. This is justified on policy grounds and by the fundamental purpose of s 66(2) - discussed in Part III below.

Criminal associations or group offending encourage and escalate criminality. ${ }^{5}$ The formation of a joint enterprise is in essence a mutual commitment to do crime and therefore has a heightened element of public danger. ${ }^{6}$ This is demonstrated clearly in many s 66(2) cases where the common unlawful purpose has involved gang-related violence. ${ }^{7}$ There is a public harm involved in someone participating in a crime with a group and therefore enabling or creating conditions in which crimes pursuant to that enterprise might also be committed. Many cases involve large-scale fights in a public place and frequently weapons are present. ${ }^{8}$ This risks harm to members of the public such as the victim in Edmonds who was not a member of a gang or even an associate. ${ }^{9}$

Edmonds involved a typical s 66(2) scenario and gave the Supreme Court an opportunity to clarify the approach New Zealand should take to joint enterprise offending in order to best address the policy issues outlined above. A detailed examination of the facts and reasoning is outlined in the following Part to provide a basis for the discussion of this important decision.

$4 \quad R v$ Hardiman [1995] 2 NZLR $650(\mathrm{CA})$ at 652; $R$ v Tuhoro [1998] 3 NZLR 568 (CA) at 572-573; $R v$ Rapira [2003] 3 NZLR 794 (CA) at [22]-[35].

$5 \quad R v$ Tuhoro, above $\mathrm{n}$ 4, at 599; Ben Marshall, Barry Webb and Nick Tilley Rationalisation of current research on guns, gangs and other weapons: Phase 1 (Jill Dando Institute of Crime Science, University College London, November 2005) at 11; Law Commission for England and Wales Participating in Crime (LC 305, 2007) at [3.141].

6 Marshall, Webb and Tilley, above n 5, at 11.

$7 \quad R v$ Vaihu, above n 3; Edmonds $v$, above n 1; Rameka v $R$ [2011] NZCA 75; $R$ v Hirawani CA134/90, 30 November 1990.

8 Edmonds $v R$, above n 1; $R$ v Hirawani, above n 7; $R$ v McNaughton [2012] NZHC 815; $R v$ Vaihu, above $\mathrm{n}$ 3 .

9 Pahau $v$ R [2011] NZCA 147 at [9] [Pahau $v R(C A)]$. 


\section{THE REASONING IN EDMONDS}

Edmonds is the leading case in New Zealand on the subject of knowledge of the weapon in party liability situations. ${ }^{10}$ The Supreme Court held unanimously that there is no specific requirement in New Zealand to direct a jury that a defendant must know of the weapon used in the principal offender's offence in order to be found guilty as a party under s 66(2) of the Crimes Act $1961 .^{11}$ However the Court did not discount the possibility that on certain facts a discussion of the weapon may be necessary to ensure a fair trial or provide evidence of the defendant's foresight.

\section{A The Facts}

The victim (V) was with a group of scaffolders who were associates of the Mongrel Mob and in New Plymouth temporarily. Their presence had angered local Black Power gang members; the principal offender, Mr Pahau; and four other men including Mr Edmonds (the appellant). V and the scaffolders were at a party. When he heard of their presence, Edmonds summoned the other four men and they drove to the scene. Pahau was carrying a knife and also in the car were a blunt instrument similar to a baseball bat, a gun, and possibly another knife.

The group of Black Power men loitered until they saw V and a few others making their way out of the party towards a house. Edmonds stopped the car at the top of the driveway and told the others to "go, go, go!" He retrieved the gun and stayed by the car while the others chased V's group. Pahau caught up with V just as he was trying to climb through a window into the house and stabbed him. V died soon after of his injuries. The other Black Power members had given up the chase at this point. ${ }^{12}$ Pahau was convicted of s 167 murder, participating in an organised criminal group and commission of a crime with a firearm. At trial Edmonds and two of the other men were found guilty of manslaughter and the two others were charged as secondary parties. ${ }^{13}$

\section{$B$ The Trial and Appeals}

At trial the fact that the defendants had a common unlawful purpose was not at issue due to guilty pleas from all parties to the charges of participating in an organised criminal group. ${ }^{14}$ Asher $\mathbf{J}$ found that their common unlawful purpose was: ${ }^{15}$

10 Edmonds $v R$, above $\mathrm{n} 1$.

11 At [52].

12 At [3]-[6].

$13 R v$ Pahau HC New Plymouth CRI-2008-043-4555, 16 August 2010 [R v Pahau (HC)].

14 Edmonds $v$ R, above $\mathrm{n} 1$, at [9].

$15 R v$ Pahau HC New Plymouth CRI-2008-043-4555, 4 May 2010 at [8] [R v Pahau (Ruling No 5)]. 
To pursue the group of scaffolders, and to cause serious violence by the use of weapons to somebody in the group of scaffolders, and to assist each other with that purpose.

The jury was further directed that: ${ }^{16}$

You will only find that Mr [Edmonds] had the requisite knowledge if you are satisfied that he knew that Mr Pahau was carrying a weapon at the time that he and Mr Pahau began to carry out the common unlawful purpose.

The common purpose alleged by the Crown omitted any mention of the use of weapons. ${ }^{17}$ The Crown also sought to argue that no direction as to knowledge of the weapon was required. In contrast, the defendants submitted that the jury must find they had knowledge of the specific weapon used in order to be guilty. Asher $\mathbf{J}$ elected to take a conservative approach and reached a "compromise" in his direction, requiring that the defendants knew Pahau had $a$ weapon but not the specific weapon used. ${ }^{18}$

The Court of Appeal considered strongly that it was unnecessary for the appellants to have known of the specific weapon used. ${ }^{19}$ The Court considered that to require such knowledge would undermine the purpose of s 66(2) in punishing collateral offences to serious group violence. ${ }^{20}$ Their Honours agreed with Asher J, however, that deciding whether knowledge of $a$ weapon was needed was sometimes necessary. This would be a question of judgement based on the facts of the individual case. $^{21}$

The appeal to the Supreme Court was confined to Edmonds' manslaughter conviction and focused specifically on Asher J's jury direction. The appellant submitted that Asher J should have directed the jury that it could only find him guilty if it was sure that he knew that Pahau was carrying the knife when he chased after V. ${ }^{22}$

\section{The Supreme Court}

The Supreme Court took the opportunity to thoroughly examine the role of knowledge of the weapon in s 66(2) party liability. Their Honours concluded that there is no legal requirement to direct that a defendant must have known of a weapon to be guilty as a secondary party. The Court

16 At $[8]$.

17 Edmonds $v$ R, above n 1, at [9].

$18 R$ v Pahau (Ruling No 5), above n 15, at [19]-[21].

19 Pahau v $R(C A)$, above $\mathrm{n}$ 9, at [49].

20 At [49].

21 At [53].

22 Edmonds $v R$, above n 1, at [2]. 
emphasised that the material question was whether the defendant knew that the ultimate result was a probable consequence of the common unlawful purpose. This is a less conservative direction than can be found in many recent judgments of the lower courts. A discussion of this apparent divergence is included further below.

The Court further refused to follow the English courts by adopting a version of their "fundamentally different" rule. The basis for this is investigated and analysed in Parts III and IV of this article. However William Young $\mathbf{J}$ (giving the reasons of the Court) noted that in some circumstances, investigating a defendant's knowledge of the weapon could be a practical requirement in order to establish their mens rea. ${ }^{23}$ This built upon and confirmed his reasoning in $R$ $v$ Vaihu (Vaihu), which noted that there is a practical reality involved in directing a jury and a weapons direction could well be necessary for evidential purposes. ${ }^{24}$ Before the differing approaches between jurisdictions or the conservatism of the lower courts in New Zealand can be analysed, it is helpful to consider the basic principles underlying s 66(2). These principles and the difference in their development between jurisdictions are discussed in the following Part. For the purposes of this article, they have been termed the "process-focused approach" and the "outcomefocused approach", corresponding to the emphasis each gives to certain aspects of the offending.

\section{OUTCOME OR PROCESS?}

There appears to be a general divergence in thinking between common law jurisdictions. The "process" approach (mainly adopted in England) tends to place emphasis on the way the crime is inflicted and the defendant's knowledge of the likelihood of that conduct. ${ }^{25}$ In contrast, in New Zealand and Australia the focus is on the more general harmful outcome that the defendant knowingly risked through participation in the unlawful enterprise. ${ }^{26}$ The placing of emphasis reflects differing attitudes around the causal factors and policy implications of the crime committed collaterally to the joint offending. This Part of the article will investigate both approaches and argues that this divergence goes some way to explaining the differing treatment given to the weapon issue.

The approaches are illustrated most usefully in the content of jury directions. Generally speaking, in directions where the judge seems focused on process, the principal's act (the part the defendant must have known was a probable consequence) is characterised quite specifically. Usually directions describe it as, for example, "stabbing" or "shooting" or explicitly bring in a

23 Edmonds $v$ R, above n 1, at [48] and [52].

$24 R v$ Vaihu, above n 3, at [36]-[46].

$25 R$ v Rahman (Islamur) [2008] UKHL 45 at [18].

26 Edmonds $v R$, above n 1; $R$ v Keenan [2009] HCA 1, (2009) 236 CLR 397; for helpful commentary see Elisabeth McDonald "Student Companion: Criminal Law: $R$ v Keenan" [2009] NZLJ 145. 
question about knowledge of the weapon. ${ }^{27}$ In framing the probable consequence in a more specific way, attention is drawn to the means and actions by which it occurred as an intrinsic part of the defendant's culpability. In outcome-focused directions, the characterisation is more general and tends to be framed as: "causing grievous bodily harm", "assault" or "inflicting serious violence". 28 The latter form of direction is most commonly used in New Zealand. However some judges in lower courts have started to take a more conservative stance. For example, Asher J's jury direction in the High Court in Pahau specifically mentioned "use of weapons" - this will be explored in Part V. ${ }^{29}$ Nevertheless, the approaches in New Zealand and in England are broadly distinguishable.

\section{A Outcome-Focus}

In New Zealand, if the defendant has foreseen the risk of the outcome or harm caused by the principal's offence but not necessarily the means by which it was inflicted then they will be guilty as a secondary party. The Supreme Court in Edmonds made a firm decision to continue to focus on outcome as the basis underpinning s 66(2) liability. William Young J emphasised that foresight of the ultimate harm was the crucial consideration in such cases and stated: ${ }^{30}$

$[\mathrm{T}]$ he magnitude of the risk of death (or other serious injury) recognised by the alleged party cannot be accurately assessed by reference primarily to whether that party knew of the presence of the fatal weapon or one which was similarly lethal.

This is essentially a rejection of the "process-focused" paradigm. It is an express affirmation that in New Zealand joint enterprise liability arises when the defendant has envisaged that the harmful outcome was a probable consequence of the common unlawful purpose. Specific knowledge of the conduct or process by which the foreseen harm is caused is useful evidence in many cases but is not the primary issue. ${ }^{31}$ This sentiment echoes the reasoning in Vaihu. The majority in the High Court of Australia has also adopted a similar stance. ${ }^{32}$

The facts in Edmonds illustrate the dangers of relying on knowledge of a weapon as comprehensive evidence of a secondary party's mens rea. Edmonds intended that serious violence be inflicted on members of V's group and not only participated but was instrumental in the commission

$27 R v$ Rahman (Islamur), above n 25, at [17]-[18]; $R v$ Mendez (Reece) [2011] QB 876 at [14]; $R v$ Stringer (Ian Bryan) [2012] QB 160 at [24]-[33]; $R$ v Carpenter (Tracy Maureen) [2012] QB 722 at [8].

28 Edmonds $v R$, above n 1, at [2]; $R$ v Hirawani, above n 7; $R$ v Rapira, above n 4, at [13]-[17] and [27].

$29 R v$ Pahau (HC), above n 13, at [8]. See also the directions in $R v$ Vaihu, above $\mathrm{n} 3$, at [30] discussing Judge Boshier's directions at trial; and $R v$ Rapira, above $\mathrm{n} 4$, at [17] discussing Fisher J's trial directions.

30 At [45].

31 Edmonds $v R$, above n 1, at [48].

$32 R v$ Vaihu, above $\mathrm{n} 3$, at [44] per Heath $\mathrm{J}$ for the majority and at [86] per William Young $\mathrm{P}$ in the minority; $R v$ Keenan, above $\mathrm{n} 26$. 
of the common unlawful purpose. It follows that his lack of awareness that the principal had a knife and would stab $\mathrm{V}$ as the method of inflicting this foreseen serious violence should not absolve him of culpability. Regardless of his knowledge of the specific weapon, he had envisaged the serious violence as a probable consequence of the attack on V's group and, further, had armed himself with a gun. This view is consolidated by the rulings in $R v$ Tomkins (Tomkins) and $R v$ Rapira, which emphasise that if the defendant knows a weapon is present and it is then used to kill, a verdict of manslaughter will be open. ${ }^{33}$

In England the same facts as Edmonds may have resulted in an acquittal if a jury considered that stabbing was fundamentally different to the beating or assault that Edmonds allegedly foresaw would happen. ${ }^{34}$ However the aim of s 66(2) is to punish and hold people responsible for collateral harm when they offend in a joint enterprise. This aim would be unfulfilled if those who foresaw and willingly risked the ultimate collateral harm are acquitted because they had not predicted the precise actions causing it.

\section{B Process-Focus}

In contrast to the "outcome-focused" approach, the majority of English judges have adopted an approach that places a greater emphasis on the way in which the principal's offence takes place. If the defendant is unaware of a specific weapon used in the principal's offence or the degree of dangerousness it poses, this will be considered a fundamental divergence from the common purpose and the defendant will not be liable. ${ }^{35}$ The law of joint enterprise liability in England runs a primarily objective test that turns on the nature of the principal's conduct and actions rather than strictly on the consequences knowingly risked through participation in the common unlawful purpose. ${ }^{36}$ The knowledge of weapons present in prosecuting the common unlawful purpose seems to be heavily influential in the question of the defendant's foresight of the principal's conduct or actions. ${ }^{37}$

$33 R v$ Tomkins (1985) 1 CRNZ 627 (CA) at 629; $R$ v Rapira, above n 4, at [34]-[37]; Karen Harvey-Vallée Garrow and Turkington's Criminal Law in New Zealand (online looseleaf ed, LexisNexis) at [CRI66.9]

34 However it should be noted that, in part, this is because England does not have the delineation that exists in New Zealand between s 66(2) and s 66(1) liability cases. Under s 66(1), New Zealand law requires that the defendant knew of any weapon used in the principal offence before he or she is convicted.

$35 R v$ Rahman (Islamur), above n 25; $R$ v Uddin (Rejan) [1999] QB 431 at 441; AP Simester and others Simester and Sullivan's Criminal Law: Theory and Doctrine (4th ed, Hart Publishing, Oxford, 2010) at 238.

36 Simester and others, above n 35, at 238.

$37 R v$ Rahman (Islamur), above n 25, at [68] per Lord Brown; David Ormerod " $R v$ Yemoh and Others: joint enterprise - murder - manslaughter - whether what stabber did fundamentally different from what contemplated by co-accused" (2009) 12 Crim LR 888 at 889 and 891. 
This "process" approach still focuses on what the defendant foresaw as an outcome but puts far more emphasis on the actions of the principal. It proposes that the only way to accurately assess the extent to which the defendant foresaw the offence to be a probable consequence is to focus on the defendant's knowledge of the weapon used or weapons similarly lethal in nature. ${ }^{38}$ This has developed in England into the "fundamentally different" rule - if the conduct of the principal was fundamentally different to what the defendant foresaw they would not be guilty as a secondary party. ${ }^{39}$ This rule will be discussed in greater detail in Part IV.

There are limits to the British focus on process and it is by no means so dominating that the foresight of the harmful outcome is ignored. Nevertheless in more borderline situations English courts frequently turn to inquire about the process or actions of the principal in inflicting the harm. If that process was unforeseen by a defendant, the court has been persuaded in several cases to acquit them on this basis. The preoccupation with the weapon and actions of the principal explains to some extent the perceived need to add knowledge of the weapon considerations into the legal doctrine.

\section{Preferring the Outcome Approach for New Zealand}

The process approach does not fit comfortably with the basic principles of s 66(2) liability. The fundamental basis of s 66(2) is the defendant's participation in the common unlawful purpose. ${ }^{40}$ Doctrinally it is not important whether the defendant authorised the principal's offence or even wanted it to happen. The culpability is derived from their willing participation in criminal activity and foresight that such activity could well lead to collateral harms. ${ }^{41}$ Resting s 66(2) liability on an assumption that the defendant's participation in the common unlawful purpose contributed to the principal offence can often distort the analysis. ${ }^{42}$ If secondary liability in s 66(2) cases were derived directly from the principal's offence it would usually be able to be classed as s 66(1) aiding or abetting. While there are sometimes fact scenarios where a defendant could be charged under either subsection, the basis of liability differs between the two. A defendant's liability under s 66(2) stems from their own criminal behaviour in conjunction with the harm caused by the principal offender. It is therefore hard to justify a refusal to apply liability because the defendant did not know exactly how harm would be perpetrated if the harm that occurred was foreseen as a probable consequence of the unlawful purpose.

$38 R v A$ [2011] QB 841; David Ormerod "Murder: joint enterprise - directions to jury" [2011] Crim LR 61 at 62 and 64 .

$39 R v$ Rahman (Islamur), above n 25, at [20], [24]-[27] and [62]; see also Ormerod, above n 38, at 64.

40 AP Simester "The Mental Element in Complicity" (2006) 122 LQR 578 at 597; Gerald Orchard "Parties to an Offence: The Function of s 66(2) of the Crimes Act" [1988] NZLJ 151 at 152.

41 Simester, above n 40, at 598-600.

42 Simester, above n 40, at 595. 
The majority in Vaihu discussed the doctrinal uneasiness with imposing a legal requirement to consider knowledge of the weapon: ${ }^{43}$

The ... distinction between knowledge of different types of weapons is problematic ... For example, in the case of a charge of causing grievous bodily harm with intent to do so, it does not really matter whether the weapon is sharp or blunt: a probable consequence of the use of each is the infliction of really serious harm. It is also difficult to distinguish between knowledge of the likely use of a blunt weapon and the consequences of embarking upon a large-scale fistfight, a probable consequence of which was the infliction of really serious harm.

Using knowledge of a weapon as a benchmark for foresight of the probable consequences of the common purpose will not always give an accurate reflection of the risk the defendant contemplated. It therefore distorts the analysis and detracts from the purpose of the section which is to establish what the defendant knew was a real risk of participation in the common purpose and punish the defendant for their affiliation with the enterprise if that outcome eventuates. Doctrinally, knowledge of a weapon is a matter of evidence, not law. ${ }^{44}$

The process approach is a response to worries of over-criminalisation in England, which are the subject of much public debate and media attention. ${ }^{45}$ Due to the nature of the common law joint enterprise liability doctrine, a party to an assault can be guilty for a resulting murder if they foresaw the mere possibility of an assault with an intention to cause grievous bodily harm, without foresight of a risk of death. However these concerns are more relevant to the English common law than the codified provisions of New Zealand or Australia, as the scope for this sort of criminalisation in New Zealand only occurs if the principal is charged with s 168 homicide; a far more rare charge than s $167 .{ }^{46}$

Much of the effect of over-criminalisation in New Zealand can be attended to through sentencing of secondary parties or by leaving manslaughter open to juries in situations of culpable homicide. In instances of homicide the defendant can be found guilty of manslaughter even though the principal may be convicted of murder, which alleviates some concern surrounding overcriminalisation. ${ }^{47}$ Manslaughter findings reflect lower states of mental culpability and foresight

43 At [39]-[44]; $R$ v Hartley [2007] NZCA 31, [2007] 3 NZLR 299.

44 JC Smith "Accessories and Joint Enterprise" [1998] Crim LR 48 at 50.

45 Edmonds $v$ R, above n 1, at [28]-[29].

46 Edmonds $v R$, above $\mathrm{n}$ 1, at [28]-[29]; $R$ v Keenan, above n 26; Criminal Code Act 1899 (Qld), s 8; McDonald, above n 26; for public debate see Owen Bowcott "Anti-gang efforts hampered by legal confusion, warn MPs" The Guardian (online ed, London, 17 January 2012); Anita Davies "A more American legal model for gang violence?" The Guardian (online ed, London, 25 July 2011); Liz Mackean "Use of Joint Enterprise Law Under Scrutiny" BBC Newsnight (online ed, London, 1 November 2011).

$47 \quad R v$ Tomkins, above $\mathrm{n} 33 ; R v$ Rapira, above $\mathrm{n} 4$. 
while still recognising the defendant's awareness of some risk of death. For less serious violent crimes, sentencing options that reflect lower culpability are open if a judge considers them more appropriate.

The outcome-focused approach better realises the purpose behind s 66(2). It is also much clearer and simpler to direct juries on. A process-based approach is likely to result in a "not guilty" verdict in situations where the defendant has foreseen the resulting harm but did not realise it would be inflicted by a stabbing instead of the expected severe beating. In such a scenario the defendant should be guilty because the ultimate harm was foreseen and risked in the course of the defendant's participation in the joint enterprise.

Socially it is important that there is recognition of the danger and harm involved in participating in unlawful enterprises and a denunciation of that harm. Allowing juries to get caught up in the process leading to the collateral crime would stray from this function and the purpose of s 66(2) liability. This does not disregard the relevance of the knowledge of the weapon for evidential purposes. However what is material for the operation of s 66(2) and the New Zealand context is that the appellant knew that the ultimate result was a probable consequence, not that he foresaw the "exact concatenation of events" that brought the result about. ${ }^{48}$ The next part of the article will investigate the effects that the more process-focused approach has had on English joint enterprise liability principles.

\section{THE "FUNDAMENTALLY DIFFERENT" RULE}

The "fundamentally different" rule has been incorporated into the English approach to joint enterprise liability cases. It is an attempt to reduce over-criminalisation, a particularly sensitive issue in England due to the operation of the common law party liability rules. While the test does not apply only to issues of knowledge of the weapon, these considerations appear to be central to the analysis. ${ }^{49}$ The Supreme Court expressly rejected the rule's adoption in New Zealand. This Part of the article will examine the advantages and drawbacks of the rule and conclude that the Court was correct to reject it. A "fundamentally different" rule would be inappropriate for the New Zealand context and would sit uneasily alongside the statutory language and purpose.

In England if the principal's actions are "fundamentally different" from anything contemplated by the defendant, the defendant will not be liable. ${ }^{50}$ This sounds similar to the New Zealand qualification that liability will be avoided if the principal offence is a total departure from the common unlawful purpose. There is some suggestion in the House of Lords judgments in $R v$ Rahman (Islamur) (the leading English authority on this point) that initially the rule was intended to

48 Edmonds $v$ R, above n 1, at [54].

49 Edmonds $v R$, above n 1, at [45].

50 Smith, above $\mathrm{n} 44$, at 50 
be another way of assessing "total departure" from the common purpose. ${ }^{51}$ However the "fundamentally different" test has been applied in a wider set of situations. While the "fundamentally different" criteria will always be fulfilled in instances of "total departure", not all situations in which the principal's actions are established as "fundamentally different" would be classed as a total departure from the common purpose in New Zealand.

One example of a situation in which the rule would apply is if the defendant foresaw that the principal might "kneecap" V intending to cause serious harm and the defendant also realised that the kneecapping might well result in death. However, if the principal intentionally killed $\mathrm{V}$ in some different way with a different weapon, such as by stabbing, then the defendant could take advantage of the "fundamentally different" rule. ${ }^{52}$ If the principal uses a weapon that the defendant did not contemplate, or uses the envisaged weapon in an unexpected way, then the rule will come into play. ${ }^{53}$ This would not be the case in New Zealand. On the above facts a different weapon alone would not absolve the defendant or constitute a major departure from the common unlawful purpose.

The majority in $R v$ Rahman felt that an act could be regarded as fundamentally different if the principal uses a weapon of which the defendant knows nothing or if the weapon is more lethal than any weapons the defendant contemplated might be used. ${ }^{54}$ Unfortunately this attempt at clarifying the law has not succeeded; there have continued to be a number of new appeals and attempts to define this area in English courts. ${ }^{55}$ The establishment of clear guidelines is hampered to a large degree by the heavily factual nature of the question.

The application of this rule in England has produced inconsistent outcomes. ${ }^{56}$ In some cases the result is too generous to the defendant. For example (using the facts in $R v$ Rahman), if the defendant foresaw grievous bodily harm with the possibility to cause death would be inflicted on $\mathrm{V}$ by beating them with bats and the principal inflicted grievous bodily harm causing death (murder) by stabbing then the defendant would be able to successfully argue that the principal's stabbing was fundamentally different. ${ }^{57}$ Therefore the defendant will avoid conviction even though they foresaw

51 At [70] and [80]-[89].

52 Attorney General's Reference (No 3 of 2004) [2006] Crim LR 63; R v Powell (Anthony Glassford) [1999] 1 $\mathrm{AC} 1$ (HL) at [15].

53 Law Commission for England and Wales, above n 5, at [2.85]-[2.88].

$54 R v$ Rahman (Islamur), above n 25, at [68] per Lord Brown.

55 Ormerod, above n 38, at 65.

56 David Ormerod "Joint enterprise: In course of a joint enterprise to inflict unlawful violence the principal kills with an intention to kill which is unknown and unforeseen by a secondary party" [2007] Crim LR 721 at 725 .

$57 \quad R$ v Rahman (Islamur), above $\mathrm{n} 25$. 
the consequence of the common purpose - grievous violence risking death. In other situations the result produced by applying the fundamentally different test is unduly harsh. For example (as suggested by the English Law Commission) the principal may do the exact act foreseen by the defendant. To the principal the act might have been intentionally lethal but the defendant may have foreseen only the infliction of harm, not death in any form. ${ }^{58}$ In such cases, the defendant would not escape liability for homicide even though they did not foresee the ultimate harm as a probable consequence. However their conviction would most likely be manslaughter rather than murder. Other issues surrounding application of the rule have arisen with regard to the relevance of the principal's state of mind and the degree of difference of weapon required to trigger a sufficiently fundamental difference. ${ }^{59}$

The "fundamentally different" rule distorts the basic principles of common purpose liability. It pulls the focus of juries away from the foreseen consequences of the common purpose and instead, directs the inquiry to which of the principal's likely "acts" had been foreseen. This fails to recognise and punish the full scope and impact of the defendant's participation in the common purpose. Further, in some cases the application of the "fundamentally different" test is unduly harsh, making the over-criminalisation justification less persuasive. If the ultimate harm was appreciated, has occurred, and the defendant has already associated himself or herself with a criminal enterprise, then according to first principles, liability is established. As was discussed above, the "fundamentally different" test produces inconsistencies of outcome. It also adds another layer of complexity to an already difficult area of law and to already confusing jury directions.

Of course, avoiding over-criminalisation is very important. It is absolutely a relevant consideration for the application of s 66(2) in New Zealand. It could also be argued that it is better to take an overly cautious approach and provide directions that are appropriately friendly to the defendant at trial. Imposing liability for someone else's actions onto another person should not be taken lightly and secondary liability for homicide or other serious criminal activities carries equally harsh penalties. However as will be discussed below, the fundamentally different rule is not the best approach for guarding against these problems.

\section{A Rejecting the "Fundamentally Different" Rule in New Zealand}

The Supreme Court in Edmonds refused to adopt the "fundamentally different" rule and distinguished the context in New Zealand from that in England for three main reasons. First, New Zealand joint enterprise liability law is codified in the Crimes Act 1961, meaning it is less open to

58 Law Commission for England and Wales, above n 5, at [B.149]; see for example $R v$ Gilmour [2000] $2 \mathrm{Cr}$ App R 407 (CA Northern Ireland).

59 Law Commission for England and Wales, above n 5, at [2.88] and [2.89]; at issue in $R v$ Mair (Sydney) [2002] EWCA Crim 2858; $R$ v Uddin (Rejan), above n 35. 
judicial development than the law in England. ${ }^{60}$ Second, the wording of s 66(2) of the Crimes Act does not allow for the application of a "fundamentally different" style rule. ${ }^{61}$ Third, there is a lower risk of over-criminalisation in homicide cases in New Zealand compared to England. ${ }^{62}$ The Supreme Court also felt that the "fundamentally different" rule was "indeterminate legally and factually". ${ }^{63}$ It stated further, " legal principles which depend on a comparison of the dangerousness of weapons encourage attempts to make unmeritorious (and perhaps faintly ludicrous) distinctions". ${ }^{64}$ These reasons will be discussed in turn in this Part of the article.

Because the law for joint enterprise liability is recorded in s 66(2), there has been less judicial development in this area and there is no scope for adding new rules to the process of determining $\mathrm{s}$ 66(2) crimes. Inserting the "fundamentally different" rule into s 66(2) would require legislative action. Judges would be stretching the underlying purpose of the section if they were to do so independently of Parliament. Section 66(2) allows only one level of risk undertaken by the party knowledge that the harm may well happen in the course of the common unlawful purpose. However the fundamentally different rule adds a new and more specific level of risk that changes the threshold for liability. The addition of this rule would strain the wording and meaning of the section, which is deliberately broad and unconstrained by variables pertaining to the process by which commission of the ultimate harm occurs.

The limit on over-criminalisation in New Zealand comes from the requirement that the principal's offence must be done in the commission of the common purpose; liability is not extended to a party for acts that are a total departure from the collateral offence they anticipated. The option of a manslaughter finding when a principal is convicted of murder provides a further check. New Zealand does lose some flexibility by disallowing judicial development of joint enterprise liability. However the current law is still in step with reality, and judicial decisions such as the inclusion of a "knowledge of a weapon" direction for evidential reasons are not prevented.

By codifying joint enterprise liability New Zealand has avoided the increasing complication that has been experienced in England. Kirby $\mathbf{J}$ has stated, "this part of the common law is a mess. It is difficult to understand. It is very hard to explain to juries. "65 The Law Commission for England and Wales has also echoed these sentiments in its 2007 report Participating in Crime. ${ }^{66}$ The

60 At [23].

61 At [47].

62 At [26]-[29].

63 At [46].

64 At [45].

65 Clayton v The Queen [2006] HCA 58 at [45].

66 Law Commission for England and Wales, above n 5. 
"fundamentally different" test does not appear to have clarified or simplified the common law at all. In fact, it has caused more confusion and less certainty in an area that is already very difficult to direct juries on. It is significant that the Law Commission has recommended legislating for joint enterprise liability in England and even more significant that its suggested draft law does not include a fundamentally different test or anything analogous to one. ${ }^{67} \mathrm{In}$ fact, the recommended wording is almost identical to the New Zealand s 66(2) and similar legislation in Australia. ${ }^{68}$

\section{B Total Departure from the Common Unlawful Purpose}

The Supreme Court did acknowledge that criminal liability might sometimes rest on value judgements similar to those in the "fundamentally different" rule. ${ }^{69}$ There is scope in s 66(2) for argument that a principal's conduct was a total departure from the common purpose. However the Court expressed a preference for a concrete assessment rooted in the facts of the case. ${ }^{70}$ Increasing the discussion in trial over when a principal's act will constitute a total departure from the foreseeable consequences of the joint enterprise would be beneficial for clarifying jury directions in this area. It is also a more appropriate alternative to a "fundamentally different" rule. Framing directions in this way will encompass the cases in which knowledge of a weapon may truly be pivotal to a finding that the defendant was innocent. It will also avoid situations in which concern with the type and nature of the weapon is such that the court loses sight of the purpose of s 66(2). This approach is more conceptually appropriate for cases where weapons are a pivotal consideration in the factual context.

The test for total departure is entirely factual and based on a judgement call over whether the principal's act was done in prosecution of the common purpose. This, the Court considered, was preferable to determining general rules for departures such as those that have been attempted through the "fundamentally different" test. Keeping to a broad test for total departure allows for the flexibility that may otherwise be lacking due to the codified nature of our joint enterprise liability. However once again it will merely be a factual or evidential issue whether or not use of a weapon will bring the principal's action beyond the scope of the common unlawful purpose.

To conclude, the fundamentally different rule is not a good basis for the legal doctrine of joint enterprise liability. It is unclear, results in unequal application and has encouraged difficult and perhaps unnecessary distinctions in England. It would also require departure from the basic principles of joint enterprise liability and s 66(2). There is already a satisfactory limitation in place in the "total departure" qualification, as discussed above. The over-criminalisation risk is not such a

67 Law Commission for England and Wales, above n 5, at [1.46] and Appendix A.

68 Criminal Code Act (Qld), s 8; see $R v$ Keenan, above n 26, for Australian application.

69 Edmonds $v R$, above n 1, at [46].

70 At [46]. 
compelling point in New Zealand. Because of the structure of the statutory regime this issue does not require the same weight as it is given in the English courts. ${ }^{71}$ As the Supreme Court stated: ${ }^{72}$

... there is no scope for a liability test which rests on concepts of fundamental difference associated with the level of danger recognised by the party. All that is necessary is that the level of appreciated risk meets the s 66(2) standard.

Having established this basis for rejecting the "fundamentally different" rule, it is now necessary to analyse the approach taken by the New Zealand courts and consider some of the practical implications of the application of s 66(2) at trial.

\section{CONSERVATIVE JUDGMENTS IN LOWER COURTS}

The Supreme Court in Edmonds gave an explicitly clear indication of the New Zealand stance in regard to knowledge of the weapon in s 66(2) cases. Strictly speaking there is no need to include reference to the defendant's knowledge of the presence or use of a weapon by the principal offender, although it may be required in some cases in order to establish the outcome foreseen by the defendant or a similar evidential matter. Jury directions in s 66(2) trials involve multiple defendants and complex questions regarding mens rea. The judge must ensure that the direction is understandable to the jury, legally correct, focuses the jurors' minds on the relevant issues, and is fair to the defendant without ignoring the Crown. ${ }^{73}$ This Part of the article will examine the way that trial judges have sought to juggle these issues in their jury directions.

Despite the view expressed by the Supreme Court, which is similar to previous decisions such as that of the majority in Vaihu, ${ }^{74}$ jury directions in many s 66(2) trials appear to lean towards a more conservative approach in which knowledge of the weapon was included in the jury direction as a matter of course. ${ }^{75}$ This conservatism seems to be based on the approach that William Young P recommended as a model jury direction in Vaihu. ${ }^{76}$ His Honour noted there that in some instances it might be impossible for a jury to infer the knowledge required for s 66(2) liability unless the

71 CMV Clarkson "Complicity, Powell and Manslaughter" [1998] Crim LR 556 at 558.

72 Edmonds $v R$, above n 1, at [47].

73 Robert Lithgow "Criminal practice: a complex murder trial" [2003] NZLJ 416 at 416

74 See for example $R v$ Vaihu, above n 3, at [45]; Reddy $v R$ [2011] NZCA 184, [2011] 3 NZLR 22 at [44][46]; $R v$ Waho CA319/04, 27 April 2005 at [29]-[31]; $R v$ Rapira, above $\mathrm{n} 4$, at [17]-[20] quoting jury directions at trial.

75 See $R v$ Vaihu, above $\mathrm{n} 3$, at [30] quoting the judge at trial; $R v$ Rapira, above $\mathrm{n} 4$, at [17] quoting the judge at trial; $R v$ Hirawani, above $\mathrm{n} 7$, at 6; $R v$ McNaughton and Others HC Nelson CRI-2010-442-000026, Jury Memo of Miller J; $R v$ McNaughton, above $\mathrm{n} 8$, at [28] and [29] .

76 At [96]. 
defendant was aware that members of their party were armed. ${ }^{77}$ Several trial judges have chosen to give conservative direction for similar reasons of evidential necessity based on an assessment of the facts of the case. ${ }^{78}$ This approach may also reflect a desire to provide the most clear jury direction possible, to prevent appeals on weapons issues, and to give the benefit of the doubt to the defendant. To analyse this pattern further, Asher J's ruling detailing his directions to the jury in the Pahau trial will be examined. This ruling is one of the latest reported examples of a High Court trial jury direction and also involves a very helpful breakdown of Asher J's reasons for adopting the stance that he took.

\section{A Asher J's Directions in the Pahau Trial}

In his Ruling (No 5) of 4 May 2010 Asher J detailed his reasons for electing to give a conservative jury direction at trial. His Honour directed that the common unlawful purpose was to cause serious violence "by the use of weapons" to those in the victim's group. The jury direction stated that they should find the secondary party guilty if satisfied that he knew that killing (with the mens rea for either murder or manslaughter) would occur as a probable consequence of the common purpose but only if the jury was satisfied that the secondary party knew Pahau was carrying a weapon. ${ }^{79}$ This direction appears to have been influenced by the judgment of William Young P in Vaihu, specifically the President's (as he then was) instructions as to how he would have summed up had he been the trial judge in that case. ${ }^{80}$ However William Young $\mathrm{P}$ stopped short of requiring knowledge of the specific weapon used. ${ }^{81}$

Asher J's reasons for taking this conservative approach were, first, that in Pahau the defendants were not physically or geographically proximate to the principal's attacks. Therefore they were less directly involved. ${ }^{82} \mathrm{He}$ was also concerned that the charge of manslaughter had more serious implications for the defendant than if it were a lesser offence such as assault. The Judge's third reason for his conservative stance was that while the pitching of the common unlawful purpose indicated the level of violence involved, it did not indicate the type of violence that was foreseen by

77 At [88]; see also $R v$ Hirawani, above $\mathrm{n} 7$.

$78 R v$ Doctor CA366/92, 20 July 1993 at 4; $R$ v Pahau (Ruling No 5), above n 15, at [8]; Pahau $v R(C A)$, above $\mathrm{n} 9$, at [52]; Rameka $v$, above $\mathrm{n}$ 7, at [144].

$79 R$ v Pahau $(H C)$, above $\mathrm{n} 13$, at [9].

$80 R v$ Vaihu, above n 3, at [97].

$81 R v$ Pahau (Ruling No 5), above n 15, at [20].

$82 R v$ Pahau (Ruling No 5), above n 15, at [27]. 
the defendants. ${ }^{83}$ The judge maintained that to justify guilt under s 66(2) the defendant must have been able to foresee "an act of violence broadly of the same type that was administered". 84

Asher $\mathrm{J}$ did acknowledge that a direction involving a weapon would be a judgement call based on the context of each case and would not always be necessary. However, we can see from this ruling and other recent trials cited above that it is becoming standard practice to include knowledgeof-the-weapon elements in jury directions regardless of the rulings from higher courts. It is notable that his Honour felt that terms such as "assault" or "grievous injury" were too general in showing what was foreseen as a probable consequence. He seemed to want to confirm that the parties had envisaged broadly the same type of violence as was inflicted. This is a narrower requirement of risk and foresight than the principles of the section require.

Asher J's reasoning that knowledge of a weapon is required to indicate the type of violence foreseen must be rejected, as must his discussions on geographical proximity. To begin with, using geographical or physical proximity as an indication of less direct involvement does not hold true as a principle. Perhaps in some instances being physically distant at the moment of the principal's crime would cast doubt on the defendant's foresight. However in Edmonds the defendant had facilitated and directed the attack on V's group and was armed with a gun while he waited by the car. It is difficult to see how this warrants an inference that he was less directly involved because he was not immediately present when Pahau stabbed V. Further it cannot be assumed that knowledge of the variety or "dangerousness" of weapon used will in itself assist in predicting the type of violence the principal may inflict. For example, a gun known to a defendant may not have been discharged as expected but used as a blunt instrument to beat a victim. This is a very different "type" of violence to shooting, although both may produce equally serious (and foreseen) injury.

Much of Asher J's argument looks similar to the reasoning supporting the "fundamentally different" rule in England. The Supreme Court in Edmonds specifically rejected the option of adopting an approach similar to the "fundamentally different" rule. In New Zealand the way in which the violence was inflicted (that is the type of violence) will not matter, as long as the level of violence was foreseen and the principal's offence was not a total departure from the common unlawful purpose. It is submitted that a consideration of the resulting level of violence or crime inflicted is a more sound principle to base the analysis on, as was discussed in Parts III and IV. However, Asher J's other reasons for preferring a conservative approach indicate pragmatism in dealing with the evidence and an endeavour to create a clear and understandable task for the jury in the face of complex facts and a difficult legal context. The merits of this practical approach will now be discussed.

$83 R v$ Pahau (Ruling No 5), above $\mathrm{n}$ 15, at [17] and [27].

84 At [17]. 


\section{B Practicality vs Strict Adherence to Doctrine}

William Young P in Vaihu noted that, in marginal cases where knowledge of the weapon may not be fundamental to party liability, it is best practice to sum up in a conservative way nevertheless. He reasoned that such an approach gives juries a "firm and concrete base for approaching their deliberation". ${ }^{85}$ The importance of properly directing juries was also expressed in the judgment of the Court of Appeal in Tomkins, which noted (in the context of the availability of the manslaughter verdict to juries in s 66(2) cases) that "the precise jurisprudential basis ... is open to debate. More importantly, it is desirable that a test capable of being explained simply and understood readily should be given." 86

William Young $\mathbf{J}$ has reminded us on more than one occasion that the reality of $\mathrm{s}$ 66(2) is that the level at which the common unlawful purpose is pitched is very important. ${ }^{87}$ Depending on the level of seriousness in the established common purpose, it may be safe to ascertain from that alone that the defendant foresaw the probability of the principal's crime. For example in Vaihu the common purpose was to go out as a group and assault the deceased. ${ }^{88}$ The defendants participated in a serious assault by kicking and beating but the principal offence involved a baseball bat. The common purpose was enough to attribute foresight of the infliction of serious bodily injury to the defendants without needing any further evidence as to knowledge of surrounding circumstances or weapons. However, the foreseen consequences cannot always be ascertained just by examining the common unlawful purpose. In those situations, evidence of knowledge of surrounding circumstances is likely to be necessary and any weapon involved will be important to the examination of those circumstances.

The Court in Edmonds also acknowledged this practical, evidential requirement for a weapons direction even though it considered that there was no legal requirement for such a direction.

Evidentially, knowledge of a weapon may be relevant to three aspects of s $66(2)$ trials: ${ }^{89}$

(a) establishing the common unlawful purpose;

(b) establishing what the defendant knew was a probable consequence of the common unlawful purpose;

(c) determining whether the principal's offence was a major departure from the common unlawful purpose.

85 At [97].

$86 R v$ Tomkins, above $\mathrm{n} 33$, at 629.

87 Edmonds $v R$, above n 1, at [49]; $R v$ Vaihu, above n 3, at [97].

88 At [45].

89 Edmonds $v$ R, above $\mathrm{n} 1$, at [48]. 
The bottom line is that no matter how unnecessary it is as a matter of legal principle, directions requiring knowledge of the weapon to establish guilt may be evidentially necessary. Such directions are likely to be included in first instance trials, especially those involving culpable homicide or serious bodily harm. ${ }^{90}$ This approach is practical and is appropriately concerned with giving the defendant a fair trial. Further, in the context of homicide it is difficult to envisage when the defendant's knowledge of a weapon is not important to the evidence pertaining to the jury's consideration of foresight of the consequences of the common purpose.

The Court of Appeal in Tomkins noted two relevant evidential points about weapons in joint enterprise liability. ${ }^{91}$ First, if a defendant is aware that a weapon such as a knife or gun is present, even merely to cause fear in the victim, there will always be a foreseeable likelihood that in the excitement of the occasion one of the party may use the weapon in a way which will cause death or serious injury. ${ }^{92}$ Second, and more importantly for the purposes of this analysis, Tomkins reminds us that the option is always available for a jury to find that the principal's offence is a total departure from the common unlawful purpose. This line will be drawn in different places depending on facts and acts as a safeguard against liability for an offence which was completely beyond the defendant's comprehension or committed for another purpose than the joint enterprise. The Supreme Court did not explicitly reject the more conservative approach in lower courts and so has left space for judicial discretion at trial over whether knowledge of the weapon need be included for evidential purposes. However, the Court did highlight that Asher J's jury direction gave too much advantage to the defendant.

The apparent dichotomy in approaches can be reconciled if directions involving weapons are acknowledged as purely evidential and procedural requirements rather than legal ones. In order to maintain consistency between the courts and avoid continuous appeals on the knowledge of the weapon point, weapons must be confined to evidential matters and the consideration of the total departure question should be improved.

\section{CONCLUSION}

The Edmonds decision has provided a clear and thorough direction on knowledge of the weapon in joint enterprise liability in New Zealand. For various reasons the Court has retained a stance that is very much based on first principles. The direct refusal to adopt an approach such as that in England indicates and affirms that an outcome-focused attitude still prevails in New Zealand. It also suggests a refusal to distort the s 66(2) analysis by inserting a test based on knowledge of the weapon into the legal principles.

90 See also $R$ v Bridge [2011] NZCA 485 at [20]-[24].

$91 \quad R v$ Tomkins, above $\mathrm{n} 33$.

92 At 629 citing Lawson LJ in $R v$ Reid (Barry) (1975) 62 Cr App R 109 at 112. 
This article argued first that the basis for divergence between jurisdictions on the knowledge of the weapon issue comes down to a broadly process or outcome-based approach. New Zealand has inclined towards a focus on the general outcome foreseen by the defendant, which has kept its considerations closer to the first principles of joint enterprise liability. This outcome-based approach is more consistent with the doctrinal underpinnings of s 66(2) liability. The process-based approach taken in England has resulted in the "fundamentally different" rule, which has arguably caused greater confusion and complexity in jury directions. This article rejects the adoption of this approach in New Zealand and agrees with the Supreme Court that it would be stretching the words and purpose of the statute to insert such a test into the legal doctrine.

Knowledge of the weapon issues have remained the subject of appeals and debate for several years in New Zealand, England and Australia. The guidance of the Supreme Court in Edmonds differed substantially from the development of this area in England. However it is a more appropriate response to the weapons issue in the New Zealand context. As the Supreme Court noted, "legal principles which depend on a comparison of the dangerousness of weapons encourage attempts to make unmeritorious distinctions". ${ }^{93}$ Further a finding that the principal's actions were a total departure from the common purpose serves to limit liability and safeguard against overcriminalisation where necessary on the facts.

Joint enterprise liability is a difficult area of criminal law: the application of another person's culpability onto a secondary party is not something to be taken lightly. It requires a clear, wellinformed jury direction and a wariness of over-criminalisation. In the years following William Young P's influential Vaihu judgment, it has become clear that knowledge of the weapon will remain an aspect of assessing s 66(2) liability on an evidential basis. It appears that most trial judges feel it is appropriately conservative to direct a jury to consider the defendant's foresight of a weapon involved in the principal offence. As a matter of practicality, this approach has several merits. However the Supreme Court has made it clear that it must remain an evidential issue rather than a point of legal principle. It is now for the lower courts to confirm in their application of Edmonds whether this judgment will halt the debate over knowledge and mens rea requirements for s 66(2) party liability in New Zealand.

93 Edmonds $v$ R, above n 1, at [45]. 
